\title{
Language Awareness
}

\section{Language awareness and language workers}

\begin{tabular}{|c|c|}
\hline Journal: & Language Awareness \\
\hline Manuscript ID & LA-1377.R2 \\
\hline Manuscript Type: & Special Issue Paper \\
\hline Keywords: & $\begin{array}{l}\text { language workers, critical language awareness, commodification of } \\
\text { language, learning and teaching relations }\end{array}$ \\
\hline Abstract: & $\begin{array}{l}\text { This paper argues that linguistic awareness and skills are essential } \\
\text { requirements for professionals whose work centres on language as a } \\
\text { process and product. Brought about by the commodification of language in } \\
\text { developed economies, language work such as brand consulting, text design } \\
\text { or online marketing requires linguistic knowledge, resources and skills that } \\
\text { many current teaching material do not provide. Extracts from interviews } \\
\text { with a diverse group of language workers allow for first insights into their } \\
\text { kind and level awareness, but also show that they are more concerned } \\
\text { about what they perceive as a lack of language awareness in their clients } \\
\text { and suggests a non-linear model of teaching and learning relations } \\
\text { between academic linguists, language workers, clients and students. The } \\
\text { paper further discusses the options that applied linguists in academia have } \\
\text { if they want to work with/as language workers and argues that engaging } \\
\text { with language work(ers) can be an opportunity to bring critical language } \\
\text { awareness and discourse analytical skills to bear on professional practice } \\
\text { and training. }\end{array}$ \\
\hline
\end{tabular}




\title{
Language awareness and language workers ${ }^{1}$
}

\begin{abstract}
This paper argues that linguistic skills and awareness are essential requirements for professionals whose work centres on language as a process and product. Brought about by the commodification of language in developed economies, language work such as brand consulting, text design or online marketing requires linguistic knowledge and resources that many current teaching material do not provide. Extracts from interviews with a diverse group of language workers allow for first insights into their kind and level of language awareness, but also show that they are more concerned about what they perceive as a lack of language awareness in their clients, suggesting a non-linear model of teaching and learning relations between academic linguists, language workers, clients and students. The paper further discusses the options that applied linguists in academia have if they want to work with/as language workers and argues that engaging with language work(ers) can be an opportunity to bring critical language awareness and discourse analytical skills to bear on professional practice and training.
\end{abstract}

Keywords: commodification of language, critical language awareness, language workers, learning and teaching relations

\section{Introduction}

To appreciate the nature and extent of language awareness in language workers, we can start by defining language workers as professionals who analyse, produce and design texts, i.e. deal with language as the object and outcome of their work. As Thurlow (2017) puts it:

we find more and more people doing work where language is not only an essential skill for securing work but is the very product of this work. This is a world where language is constantly and everywhere at work - something to be controlled and crafted, something to be bought and sold.

This definition involves a rich and varied array of occupations, all of which require awareness and skills around language. Language workers include translators and interpreters, journalists and communication professionals, branding and language 
consultants. ${ }^{2}$ Paveau (2011, p. 43) also includes editors and proof readers as a category of what she calls 'folk linguists'.

Language workers thus defined can be differentiated from people who use language as the medium of their work - most occupations fall into this category - and also from those who produce texts without that being the main objective of their work: for instance, police officers conduct and transcribe interviews (MacLeod and Haworth, 2016), but the main purpose of their work is law enforcement. In this paper, the focus will be on language awareness in professionals who work with language as the object and/or product of their work, and specifically on those who work outside academia.

Language awareness can be defined as 'an enhanced consciousness of and sensitivity to the forms and functions of language' (Carter, 2003, p. 64). For the past 30 years, the concept of language awareness has been central to approaches within language learning and teaching that seek to replace mechanistic learning based on prescriptive principles with developing learners' understanding of, and metalinguistic skills in talking about, the structures and effects of language(s). It is therefore no surprise that the concept of language awareness has been mostly applied in second language acquisition and language teaching (see also Svalberg, 2016, pp. 8-9), as well as education more broadly. Less prominent applications concern translation studies and the area of linguistic diversity, including minority languages. The predominance of educational research in studies on language awareness is reflected in Garrett and Cots (2017), whose edited handbook includes parts on learning and learners, teaching and teachers, and a part headed 'beyond language pedagogy', which includes chapters on translation as well as minority and diaspora languages.

In contrast to the well-established field of language awareness, studies of language work and workers are only just emerging. Apart from research into translating and interpreting in the context of international institutions (e.g. Koomen, 2014), previous work has addressed the processes involved in producing press releases (Catenaccio et al., 2011) as well as textbooks and other educational resources (Sammler et al., 2016). Another strand reports on the consultancy work of applied and sociolinguists outside academia, e.g. in the context of asylum applications (Patrick, 2016). However, while there is a burgeoning literature on the role of language as a commodity (see section 2) and numerous studies on 
call centres (e.g. Friginal, 2009), there is very little on professional language work and workers in a business context. This is not due to a shortage of such work taking place: as the background to the interview study (sub-section 3.2.1) will show, brand consulting, document design and corporate communications are established industries that increasingly rely on linguistic expertise. Yet hardly any of this work has been published (but see Delin, 2005; Ereaut and Segnit, 2006), partly for reasons of confidentiality and partly because few professionals straddle academia and the private, public or third sectors.

Given the focus in language awareness research on language learning and teaching, together with the emerging nature of studies on especially professional language work, it is no surprise that studies that apply language awareness to business and workplace settings have been few and far between. Over almost 25 years, there have only been a handful of relevant studies: Santos (1994) and Griffith and Labercane (1997) investigate the language awareness of non-native speakers in business, and language awareness and literacy in multicultural workplaces, respectively, a line of investigation that is continued by Codó's (2017) work on language awareness in multilingual/-cultural organisations. From a different vantage point, Weninger and Kan (2013) call for critical language awareness in business, that is 'an understanding of how one's choice of linguistic features shapes social and interpersonal relations in communicative events' (p. 61), including relations of unequal power as they are commonly found in business contexts. However, the authors are aware that

that one obstacle to introducing a critical language awareness approach in business communication has to do with ... language [being] a tool of communication or an instrument in sustaining inequality (p. 67).

We will return to this potential conflict below, in section 4. For now, it should be noted that I am broadly aligned with Weninger and Kan's (2013) agenda to introduce language, especially the critical variety, into the learning and practice of future and current business professionals.

The aims of this paper are to a) make the case that language workers need linguistically informed language awareness, which current teaching materials often do not equip them with; b) illustrate what kind and level of language awareness language workers exhibit; 
and c) discuss how applied linguists in academia can work with or even as language workers.

In order to meet these aims, the remainder of this paper is structured as follows: section 2 provides a brief overview of the literature on the commodification of language, shows what new areas of professional language work that process has brought about, and argues why language workers need language awareness. Section 3 points out the shortcomings of many business communication textbooks in providing such awareness. This leads to an introduction to the interview study with language workers, which allows for first insights into what kind and level of language awareness language workers bring to their tasks. Accordingly, common themes around language awareness are identified in the interviews and illustrated with a number of extracts. Section 4 follows on from those insights, elaborating on the notion of critical language awareness and suggesting ways in which applied linguists can become involved in raising it in current and future language workers. The latter point will be illustrated with further relevant extracts from the interviews. Section 5 concludes by discussing if and how we can solve what could be called the conundrum of the critical language worker.

\section{Language as a commodity and new forms of language work}

In developed economies, a growing service sector, an increasing knowledge economy and saturated markets combine to redefine language as a tool to 'manag[e] the flow of resources over extended spatial relations and compressed space-time relations, provid[e] symbolic added value to industrially produced resources', e.g. through brand tone of voice, 'facilitat[e] the construction of and access to niche markets' by employing minority languages and language varieties, and develop 'linguistically mediated knowledge and service industries' (Heller, 2010, p. 103). Language is now a central medium of work in both highly-skilled knowledge and low-skilled service industries, for both 'project teams that meet, talk, take notes, project data, write on whiteboards, and otherwise engage in a process of joint spoken and written labor' (Urciuoli and LaDousa, 2013) as well as call centre operators that follow highly stylised scripts (Cameron, 2000).

Weninger and Kan (2013, p. 60) point out that in such a climate, 
language is understood primarily as a means of communication [which] fits well with the instrumentalism that characterizes mainstream management theory and practice ... linguistic instrumentalism ... sees the usefulness of a language in terms of its economic value.

As language becomes a commodity to be bought and sold, crafted and designed, language awareness becomes a marketable asset in an economic order that views 'workers as entrepreneurial bundles of skills' (Urciuoli and LaDousa, 2013, p. 185).

There is indeed a burgeoning discourse on language awareness as a soft skill needed by business that uses the topos of numbers (Žagar, 2010, p. 6) as its main argument. The business case for language awareness and communicative competence centres on the cost for the economy that is brought about by the respective 'skills gap'. Below are two examples to illustrate this rather alarmist discourse, one from a US professional organisation that develops standards for, awards accreditations of and commissions research into project management, the other from a report on so-called soft skills that was commissioned by McDonald's and prepared by market research consultancy Development Economics:

$\$ 135$ million is at risk for every US\$1 billion spent on a project. Of this sum, 56 percent (US\$75 million) is at risk due to ineffective communications. (Project Management Institute, 2013)

The annual overall expected loss of production due to expected soft skills deficits is anticipated to amount to almost $£ 8.4$ billion per year by 2020 . (Development Economics, 2015)

In the UK and other countries, this gap has led to a call for universities to 'produce' graduates with the needed communication skills, reducing language awareness and reflection to a mere means to an economic end. We will return to this point, and the critique of language awareness as a mere skill, in section 4 .

For now, we need to ask what is required of these new language workers and what knowledge and skills they need. A look at practices in language consulting helps shed light 
on these questions: typically, an initial conversation between a potential client and an agency - be it in language consulting, document design or branding - is followed by the agency drafting a proposal for the client that states what they can offer. If the project goes ahead, such a proposal is shared with freelance analysts along with further briefs from the client. As such, the proposal represents the agency talking to the potential client and is usually the first indication for the analyst of what they are supposed to do in working for the client. Here is an example of a client proposals from my own consulting practice (italics added; for further examples see Delin, 2017, p. 661):

You feel that ... it has become harder for you to talk to [customers] in a way that is meaningful, simple, transparent and relevant ... you can often and inadvertently use language that does not seem 'real'.

Clearly, to operationalise and deliver the above projects requires certain knowledge and skills. The language worker who is tasked with helping the company in question sound 'meaningful, simple, transparent and relevant' first of all needs to be able to relate such effects back to specific linguistic and pragmatic features, and to understand how these work in different contexts. For example, 'simple' and 'transparent' could mean using short, paratactic sentences and non-Latinate words - yet such a style might not be appreciated by educated audiences. The client may here be thinking more of sounding less 'corporate', perhaps by avoiding abstract nouns and nominalisations. Using language to create certain effects requires the professional to have a meta-language to describe and explain the linguistic data they will be working with and any texts that they will produce. The other two adjectives in excerpt (b), 'meaningful' and 'relevant', are pragmatic functions of language use: what is considered relevant will depend on what the reader wants to know, so again, the language worker has to design any texts with an imagined audience in mind, or advise the client on how to do so. Finally, language workers also need the ability to balance establishing their credits with translating findings back into the client's language and shifting genres across contexts for different audiences.

This brief discussion shows that language workers need many complex types of knowledge, resources and skills. The next section will discuss how they can develop them.

\section{Possible sources for, and levels of, language awareness in language workers}


This section will first turn to communication textbooks as a possible source for language awareness and show how many mainstream materials offer no adequate teaching and training. (Section 4 will attend to textbooks and training materials written by applied linguists.) This brief critique will be followed by evidence from interviews with language workers to ascertain what language awareness they bring to their profession and what importance language awareness has for them.

\subsection{Communication textbooks}

It has been noted before (Chan, 2017; Creelman, 2017) that communications textbooks and other teaching and training materials can be sorely lacking in equipping language workers with the knowledge, resources and skills they need. From a range of successful corporate communications textbooks, I will take a closer look at two to see what they offer to future and current language workers: Joep Cornelissen's Corporate Communication: a guide to theory and practice ( $5^{\text {th }}$ ed. 2017) and Joseph L. Chesebro's Professional Communication at Work: interpersonal strategies for career success $\left(1^{\text {st }}\right.$ ed. 2014).

Both authors combine academic theory and evidence with a practical approach, and both present theoretical models of communication early on in their books. However, while Chesebro stays close to the mechanistic conduit model, in which information is encoded by the sender and transferred to the receiver to decode, and only adds the feature of contextual noise, Cornelissen favours a more complex circular model that places more emphasis on context. Given that Cornelissen's remit is wider than Chesebro's, who addresses workplace rather than corporate communication in general, the former author proceeds to introducing communication strategies and campaigns, as well as their effects, before focusing on specific areas such as crisis communication and corporate social responsibility. Chesebro, on the other hand, charts the communicative aspects of a professional's journey from finding and applying for a position to building credibility within an organisational culture and building workplace relationships. After that, Chesebro, too, addresses specific areas, including conflicts and disagreements as well as coaching and giving presentations.

In the context of this paper, the space that the authors devote to language is of particular interest. Here, we can see that Cornelissen stays firmly on the level of communication strategies, practices and media, which are illustrated with numerous case studies. 
Chesebro's book on the other hand features a chapter titled 'Using words skillfully' (pp. 143-163), which is presented as helping readers be more 'tactful' (p. 143) in the way they speak, i.e. use language in contextually appropriate ways. The chapter covers labelling and foregrounding/backgrounding through framing, the functions, cognitive aspects, plots and structure of stories, and types of questions, with the author pointing out the benefits of using each of these discourse functions and features (called 'skills' by Chesebro) in workplace situations. The three 'skills' are illustrated with hypothetical or anecdotal examples, and each section of the chapter lists formulae for using frames, stories and questions. This corroborates Clifton's (2012, p. 285) observation about leadership and management textbooks, namely that 'even if such popular prescriptive books do provide linguistic advice, it is usually presented in the form of simplified scripts based on intuition and recollection rather than direct observation of what actually happens'. However, Chesebro steers clear of decontextualised norms of interaction and instead describes situations in which framing, storytelling and asking questions is useful. Despite considering context, however, Chesebro's approach falls short of what could be called language awareness, in that it still advocates the 'correct production' of pre-formulated phrases rather than 'the learner's ability to explain how particular forms function' (Carter, 2003 , p. 65). In order to understand such functions and to use linguistic and communicative resources creatively and flexibly, language workers need to understand from authentic examples how language can be used to achieve certain effects across contexts.

However, there is more to language awareness than metalinguistic knowledge and flexible use of lexico-grammatical resources. Language use across contexts also needs to take into account the link between discursive and professional practice, as advanced by critical genre analysis (Bhatia, 2016). This recent approach to the analysis of text types sees them as embedded in professional contexts and forming part of professional practices. As Bhatia (2016, p. x) elaborates, critical genre analysis seeks to explain 'why and how professionals ... exploit available semiotic resources and modes of communication to achieve their professional goals'. Employing meaning resources and modes of communication that are seen as appropriate to a particular context and communicative purpose forms part of the text producer's discursive practice. Discursive practices in turn form part of wider professional practices, as 'one is significantly instrumental in the achievement of the other' (Bhatia 2016, p. 7). To take an example, Whitehouse (2018) discusses the discursive 
practice in financial communication that sees financial analysts produce text types such as earnings forecasts that are distributed without any adaptation to individual and institutional investors and to journalists. Forming part of the professional practice of communicating specialised knowledge to stakeholders, this undifferentiated form of communication may meet the organisational goal of speeding up communication while at the same time cutting costs. However, it fails to acknowledge that different audiences have vastly different levels of financial literacy and that some readers will be disempowered by highly technical texts. In this case, any language awareness that an individual writer may have is undermined by an organisational culture that lacks such awareness.

After looking at what knowledge and skills language workers need, recognising a lack in appropriate learning materials, and acknowledging the constraints of organisational goals and professional practice, I will now proceed to the question as to what language workers already bring to the job.

\subsection{Interviews with language workers}

\subsubsection{The interview study: design and partners}

This sub-section draws on 13 semi-structured interviews which reflect the experience of professionals from the private, public and not-for-profit sectors. Seven of the interviews were conducted in 2016 for a study on language workers, with the interview partners being identified through my professional networks. Being interviewed by a linguist about language work and the role of linguistics in it, and about the possible benefits of language workers collaborating with academic linguists, entailed complex face needs for the professionals, as reflected in some of their answers. Four of the interviews were done face-to-face, one on email and two more were conducted by skype. The other six interviews making up the total were published in Babel magazine (www.babelzine.com) and on the website http://careerlinguist.com/profiles-in-lingusitics/ [sic]. All published interviews had the aim to show the wide variety of language-related careers and professional profiles that can be established following a degree in linguistics. It should be noted that while the published interviews all included long quotes from the interviewees, they were likewise all edited and probably shortened.

Comprising four women and nine men, the interviewees represent a range of language workers outside academia, including brand consultants, marketing managers and 
government advisors. Of the 13 interviewees, four are based in the US, one reports on his time as advisor to the government of a small Eastern European country and the rest work in the UK. Table 1 provides an overview of the interview partners.

[Table 1 here]

The first thing to glean from this table is that language workers can be found in very different kinds of organisational settings and at different levels of seniority: a few hold their first or second job after graduating from university (PRS2, PRS3, THS12), some are senior professionals (PRS7-9, PBS 10, PBS11) and yet others have set up their own businesses (PRS1, PRS4-6, THS13). In the interviews, it moreover becomes clear that language work is done by people with a wide variety of backgrounds, including linguistics, computing, history, anthropology, film studies and journalism. In addition, language professionals use a range of linguistic frameworks, including corpus linguistics, computational linguistics, interactional sociolinguistics, linguistic anthropology (especially for the US interviewees), discourse analysis, cognitive semantics - in short, the interview partners apply whatever approach they have come across in their formal or continuing education.

The interviews conducted for the study on language workers were semi-structured and, with the exception of one short interview of 20 minutes, lasted between 30 minutes and an hour. They consisted of roughly three parts: the first featured initial questions about the research partner's educational background and current position at work, and how their career started. More pertinently, they were asked what knowledge about language they got from their degree and how they could use in their work. The second part of the interviews revolved around processes of text production or analysis, before the interview concluded with a more conceptual question about how interviewees see the relation between linguists working in academia and language workers in other contexts, and what points of shared interests and possible collaboration they would identify. That last question entailed what the interview partners thought linguists in academia had to offer to them and what they thought they had to offer to academics. Equivalent sections were identified in the published interviews. While neither the published nor the unpublished interviews were conducted with questions about language awareness in mind, the interviewees' answers still allow inferences to be drawn about that topic. 


\subsubsection{Language awareness as reflected in the interviews}

The interviews specifically conducted for the study on language workers were transcribed for their content and all interviews were subjected to close multiple reading/listening to identify what themes they addressed. These themes were then manually grouped into theme complexes and the transcripts and published interviews coded accordingly. In the specifically conducted interviews these themes naturally reflect the interviewer's questions, so all interviewees talked about what they did at university and how they use, have used or would use knowledge about language and linguistics in their professional life. The theme complex on the role of language, language awareness and linguistics is of particular interest for this paper.

Starting with the background of the people working for the interviewee's organisation, some of the language workers find themselves to be the only linguist on the team. Other interviewees do not have a background in linguistics and tend to be apologetic about it, very likely because they are being interviewed by a linguist. For example, extract 1 shows evaluative membership categorisation on part of a software engineer who co-founded a spin-out company using keyword analysis to analyse how potential customers talk about particular brands:

1. [Working with two corpus linguists] is the closest we got to a proper linguist ... so we didn't have any pure linguists on our team, more techie linguists... Because we don't have a linguist on our team, it is quite hard to translate what we do for the marketing world; we're just techies. (PRS1)

The interview situation of course has a strong influence on (self-)evaluation, and other interviewees in senior organisational positions are more outspoken about what language skills they expect in employees. The following quote from an English language graduate and then head of communications for a public television company is taken from an interview conducted just before he gave a career talk to current students:

2. We want people with good writing skills: broad vocabulary, no clichés, interesting and exciting copy. (PBS11) 
As extract 2 shows, interviewees tend to focus on effects rather than means of language use. This is made explicit in extract 3 , from the published interview with the founder of a language consulting company, who has a background in linguistics:

3. How distinctive a business's writing is, and what it says about them, is still largely down to the intuition of our writers. They pore over tens of thousands of words and spot patterns and themes, [e.g.] do some areas of the business sound more formal than others? ... The crucial next step is to make it persuasive, or warm, or surprising, or whatever effect it is you're after. (PRS5)

Achieving those effects is presented as a matter of 'intuition' rather than knowledge and skill, reflecting the gap in many communications textbooks. It should be noted though that extract 3 is from an interview that may have been shortened before it was printed, possibly editing out any detail. The same could be said for extract 2 , which is from the shortest interview conducted for the language worker study. A longer interview may have provided more in-depth discussion of linguistic means rather than just reference to desired effects.

In terms of what knowledge about language and what linguistic skills have proved useful for the interviewees, and how so, one aspect that is often mentioned is lexis. (We can read this as an echo of Chesebro's [2014] chapter on 'using words skillfully'.) For example, the two interviewees below reflect on junior positions they used to hold or are holding in central government and a think tank, respectively. Both of them were/are tasked with writing press releases:

4. Things that were a bit mystifying ... just the choice of words, very specific jargon was used, technical terms ... I would be critical towards perhaps too lengthy and complicated ways of expressing things. (PBS10)

5. A lot of deliberation [in writing press releases] is around word choices. (THS12)

The second quote also refers to syntax, specifically hypotaxis, but although the interviewee had acquired such technical vocabulary at the time of the interview and was speaking to a 
linguist, he did not use domain-specific terminology. This may be due to the fact that he was reflecting on a previous stage of his professional life when he acted more intuitively with regards to language use and text production.

Depending on their background and the requirements of their job, interviewees would show different degrees of knowledge about the more technical aspects of language, as contrasted in the following two extracts. The first of these is from an email interview with an English language and creative writing graduate, who at the time held his first position as public relations assistant for a private television channel:

6. My degree taught me how to sensationalise ("[name of interviewee] from the PR department of [name of TV channel] shares the secrets this Thursday evening') and embellish ('I was heavily involved in...'). (PRS3)

By contrast, here is a more senior online marketing manager - and linguistics graduate talking about his time at an online travel agency, where he was involved with a project on search engine optimisation:

7. at that time there was no real awareness of targeting broad sets of phrases that everyone associates with some of those key terms like 'hotels in London'. So what we did is we created a systematic approach that looks at things like concordance analysis - don't know if that's the right term - where you get sets of texts and you look at the commonly associated terms, high-frequency co-occurring terms. (PRS2)

This stretch of talk ends with a hesitation marker ('erm') and a long pause of several seconds. The interviewee struggled to find the right term (collocations) and apologised, saying that it had been ten years since he took his degree. Again we can see the interviewee trying to save his own face when speaking to an academic linguist (see also the self-deprecation in extract 1). That aside, however, the speaker refers to his linguistics degree and accounts for how it is useful for his professional life. 
The interview situations and demands of the interviewees' professional positions are too heterogeneous to allow for any general statements, for instance that a degree in linguistics leads to more language awareness. What the above extracts suggest though, however tentatively, is that for the professionals who were interviewed the focus is often on effects rather than means and that language awareness, where it surfaces, centres very much on lexis. To enable professionals to identify what linguistic strategies function effectively in a given context and to help them develop a meta-language, applied linguists need to direct attention to language-in-action, i.e. to authentic language data, and to the underlying mechanisms governing their use. Doing so would allow professionals to observe, reflect on and internalise linguistic and discursive practices. In the next section, I will therefore return to what role linguists in academia can play to increase language awareness in future and current professionals. First though it seems appropriate to report on another, perhaps less expected finding from the interviews.

Heterogeneous as though they are, the interview partners are united in being less concerned about their own language awareness - other than saving face towards the interviewer - than they are about language awareness in their clients: many speakers address the issue of how they could raise their profile with them and convince them to use the services of language workers. Seeing that the bulk of brand guidelines or 'brand books' - to give just one example - is dedicated to visual aspects rather than language (Delin, 2017, p. 664), their concern is understandable. Indeed, interview partners from a range backgrounds, positions and sectors were unequivocal on the perceived lack of awareness that potential and actual clients showed about the importance of language and the usefulness of language analysis and text production. The following extracts are taken from interviews with a number of consultants in branding, text design and health communication, and show that language workers can be quite vocal when talking about their clients' language awareness, or lack thereof:

8. I think [clients] are starting to understand that language is really important ... certainly the more advanced agencies and brands are starting to realise that, but for the majority they don't really get it yet. (PRS1) 
9. It amazes me how linguistics is still a 'secret' subject. All kinds of people assert all kinds of nonsense about language, without considering that it might be possible to design experiments to test their ill-informed prejudices! (PRS5) ${ }^{3}$

10. Sometimes as a linguist you have to explain a lot. You have to explain the value of linguistics, especially to clients ... We educate doctors on how to better communicate ... and we help patients communicate with their doctors about their condition. (PRS8)

What seems to emerge is that language workers perceive in their clients the same lack of language awareness that some academic linguists, including myself, might see in language workers. It is important to reflect on this bias and to discuss the relationship between language workers and academic linguists in less linear and hierarchical terms.

\section{Applied linguists and/as language workers}

To assume that applied linguists want to get involved with language work and language workers entails the assumption that they are either comfortable with contributing to the commodification of language or that it is possible to retain a critical stance while raising language awareness in future and current professionals. Taking the optimistic view that one can have one's critical cake and eat it brings us back to the notion of critical language awareness.

Here we can turn to a previous generation of applied linguists and literacy researchers who put forth reasons to teach critical language awareness, arguing that doing so could be socially transformative. Fairclough (1999, p. 81), for example, maintains that

[i]n a critical view of education, knowledge and 'skills' are indeed taught and learnt, but they are also questioned - a central concern is what counts as knowledge or skill ... for whom, why, and with what beneficial or problematic consequences.

He further warns that 'in passing on prestigious practices and values ... without developing a critical awareness of them, one is implicitly legitimising them, and the asymmetrical distribution of cultural capital' (Fairclough, 1992, p. 150). These words are no less, and arguably more, relevant now than they were 25 years ago. In an age where higher 
education institutions are increasingly seen - and measured - as service providers that equip their 'customers' with skills demanded by employers, it is more difficult, but also more important, to argue for critical language awareness. Sharing these concerns, Mautner (2010, p. 175) has more recently advanced that '[1]anguage awareness goes a long way towards alerting individuals, organisations and social subsystems to infiltration by another, dominant subsystem, and will help to immunise them against it'. Critical language awareness is here seen as operating not only at the level of texts, but also at the level of the discourse practice and the wider socio-economic contexts in which they are embedded: critical language awareness becomes critical discourse awareness.

But who needs critical language awareness? The early literature has traditionally discussed critical language education with regard to underprivileged - now called 'widening participation' - students. The aim of early proponents of critical language awareness was emancipatory, i.e. to enable students to both understand the role of language in their marginalisation and use language to empower themselves. But what if one's students are the future elite? Weninger and Kan (2013, p. 61) state that critical language awareness is still needed, but maintain that 'educating future executives to be more critical of discourse practices must occur in tandem with raising language awareness within all echelons of the (future) workforce'. Wallace (1999, p. 102) even claims that

there is a greater need to educate white middle-class students in critical language study which they may not otherwise feel much disposed to pursue, simply because their immediate interests are not at stake. (emphasis added)

Janks and Ivanič (1992, p. 314) elaborate on this point, arguing that awareness itself is not enough. In addition, '[1] earners need also to find for themselves ways of speaking and writing which impose less on the people they are speaking to'. Interestingly, the authors go on to say that emancipatory discourses are not only a form of resistance against dominant elites, but can also take the form of discourses that actively empower others being produced and distributed by privileged discourse participants.

We can make the case then that future elites, too, need language awareness, even critical language awareness. Yet there is no shortage of anecdotal evidence that learner preferences on business communication courses do not include critical language 
awareness. Business students in particular often do not see the need for critical language awareness and express the wish to just be taught mastery of a particular genre, such as press releases, or learn about communication strategies that will help them achieve operational goals. Employers may wish for language awareness, even critical awareness, for fairer workplaces, better customer communication, increased reputation etc. - whether for moral principles or to meet the profit motive. Whose wishes have priority though - the students', the employers' or the educators'? Contemporary higher education discourse, in the UK and elsewhere, is not only student-centred - as it should be -, but beyond that heavily influenced by consumerism (Kheovichai, 2014; Mautner, 2010, pp. 72-98; Ng, 2016). One reflection of this is the widespread use of the customer communications formula 'you said - we did', ${ }^{4}$ be it for lecturers' feedback on course evaluations, the refurbishment of the university library or increased contact hours. Such consumerist discourse instils a belief in students that their wishes have absolute priority, certainly when compared to the political agenda of an applied linguist who wishes to teach critical language awareness.

However, if applied linguists in academia insist on a critical edge in educating students and engaging with language workers, what options do they have? First of all, they can write textbooks on business and corporate communications that are informed both by systematic research and critical approaches to linguistic data. Examples include Köster and Handford (2012), Mautner (2014) and Darics and Koller (2018), who all introduce research and researchers relevant for current and future language workers. Furthermore, applied linguists can research language workers or collaborate with practitioners to combine insider knowledge, analytic language awareness (see Sarangi, 2002) and critical reflection. And finally, applied linguists can double as language workers.

The issue of academic linguists also acting as language workers relates back to the interview question on what the two groups have to offer each other. There was a broad consensus that linguists were needed to assist language work. A junior PR assistant holds that with regards to crisis communication, a regular feature of his job,

11. [i]t would be good for a comms department to sit down with linguists and for them to work together in analysing what makes for a successful approach. (PRS3) 
Some interviewees, especially those who have academic interests themselves, are passionate about collaboration between linguists in academia and language workers. A case in point is this director of global campaigns for a liberal think tank, who has a special interest in cognitive linguistics:

12. We are keen to work with universities ... I've never had any official training [in linguistics] and in fact I rely on people who have very heavily ... [Linguists] could illuminate how language keeps us locked into a certain logic ... we really need the insights of linguistics, desperately. (THS13)

Of course, the interviewees above were aware that they were talking to a linguist, so they very likely employ politeness strategies to address the interviewer's positive face.

Nevertheless, this junior project manager does point out that the wheels of academia grind very slowly:

13. it's quite hard work putting a new idea into academia because whereas on one hand we give it to business and they will run with it ...you give it to academics and obviously it needs the rigour sitting behind it [but] it makes for a very slow start. (THS12)

We again find face work here in that the speaker refers to a high standard of academic work. While this saves the interviewer's face, it also explains the different timescales within and outside academia, which can be an obstacle for collaboration. Another, more general complaint is the missing links between academia and other professions, which can lead to frustration, as shown in this quote from a former academic and now chief operating officer of a brand consulting company:

14. I got very frustrated that I was researching all this stuff and it never got used in the real world ... I got 50-odd papers but to me they are irrelevant compared to having it used in the real world. (PRS1)

The phrase 'the real world' is used repeatedly by interviewees. Constructing non-academic work as more real and hence more gratifying, perhaps even more valid, clearly does some ideological work. Similarly, what applied linguists teach is not always seen as useful by 
language workers, again because of a lack of connections between academic research and practice in 'the real world'. This recent English language graduate and junior professional reflects on this disconnect between what he learned at university and what he is experiencing in his job:

15. [The module] also opened up the topic of language in a crisis, but to be honest it's wildly different actually working on this side of it than analysing externally. (PRS3)

Where does this leave us with regard to language awareness, including its critical variety, in language workers? Extracts 14 and 15 in particular defy a simplistic model of knowledge transfer. Clearly, it is not the case that applied linguists hold all relevant knowledge and pass it on to students and language workers, who in turn educate their clients (see extracts 8-10). Instead, these processes work much more like complex systems in which knowledge is exchanged rather than transferred and roles overlap. As Svalberg (2016, p.10) elaborates:

A non-complexity ontology typically sees the world in terms of linear, predictable cause effect relationships. A complexity view regards the world in terms of dynamic interaction and interdependence between agents and factors from which phenomena emerge (rather than are caused). Emergence (e.g. of learning) is probabilistic rather than predictable.

Linguists in academia also learn from language workers, e.g. about language- and discourse-related problems faced by professionals in other sectors. This process is reinforced when applied linguists act as language workers themselves, learning from, and raising language awareness in, clients. And then there are students, whose language awareness is hopefully raised when being taught by applied linguists and possibly in career events with language workers. Figure 1 captures the complex relationships between applied linguists, language workers, students and clients, where arrows indicate learning and teaching.

[Figure 1 here] 
It is important to note that students also have agency in shaping teaching in line with their needs as possible future language workers or other professionals, even though this may conflict with educators' wish to raise critical language awareness. Teaching needs to stress that critical language awareness is not a luxury concern but can be of central importance in language work. In the concluding section, I will discuss what I refer to as the conundrum of the critical language worker.

\section{Concluding thoughts}

While it is relatively easy to make a case for how language work for, say, international development charities or public health services contribute to reducing inequality and increasing empowerment, where does the critical language worker stand with regards to private sector clients such as insurers, financial service providers or pharmaceutical companies? Is it enough to make their internal and external discourse less discriminatory less sexist, ageist and generally condescending - while helping them to (ultimately) increase revenue? My answer would be in the affirmative: while intervening in a company's discourse does not change the broad economic structures in which it operates, any increase in respect towards, and agency for, stakeholders is to be welcomed. To take but one example, Delin (2005) has shown how 'deeply branded' utility bills not only help with corporate impression management but are also consumer-friendly, helping customers to make informed decisions about budgeting and price plans. Consulting work can also involve, for instance, reducing gender stereotypes when marketing financial products to affluent women, and while such work does not address the economic, political and social structures facilitating gender pay gaps and female poverty, it does reduce the reproduction of sexist concepts in one particular domain.

Sceptics may say that this is little more than critical language awareness 'help[ing] people to conform with open eyes, to identify their feelings about it, and to recognise the compromises they are making.' (Janks and Ivanič, 1992, p. 318). However, I would like to end on the more optimistic note struck by Mautner (2010, p. 184, n.15): talking about inhouse communications training at higher education institutions, she points out that

linguists who help deliver such programmes ... face quite a dilemma. On the one hand, it's because of their academic background and linguistic expertise that they are in a better position than many self-styled communications trainers to develop balanced 
and analytically sound training modules which avoid a grossly oversimplifying transfer of 'customer orientation' from the private sector to higher education. On the other hand, it is this very background and expertise that makes linguists ... the most ardent critics of importing commercial concepts and discourses into academia.

According to the author, '[t]he dilemma can be resolved by opting for a constructively critical approach which puts language awareness centre stage', using language 'to convey courtesy, empathy and professionalism without mimicking the customer-service discourse of the commercial sector' (ibid). This programmatic statement captures how applied linguists-cum-language workers can use language awareness to intervene in a discourse to empower stakeholders.

In this paper, I have made the case why linguistic knowledge, skills and resources, in short language awareness, are essential requirements for language workers. I have also pointed out how mainstream communications textbooks are not necessarily the best source to equip language workers with such awareness, quoting evidence from interviews with language workers to illustrate what kind and level of language awareness can be found in a diverse group of interviewees. I then problematised how critical language awareness can be communicated and maintained. This led to a discussion of the complex teaching and learning relations between academic linguists, language workers, clients and students, which can raise language awareness in all of these different groups. Such language awareness increases the quality of language work while critical language awareness can in addition have empowering consequences for customers, employees and other stakeholders. At a time where the so-called 'impact agenda' in the UK and elsewhere puts pressure on academics to justify the value of their work by making it relevant to 'the real world', linguistically aware language work, including from a critical perspective, has the potential to turn such pressure into an opportunity.

\section{Notes}

${ }^{1}$ I would like to thank Crispin Thurlow, whose invitation to a research symposium on language work in Bern (January 2016) initiated this study. Further thanks are due to the organisers of the Association of Language Awareness annual conference in Vienna (July 2016), whose invitation to give a plenary lecture helped me focus the research. Finally, I 
am grateful to the two anonymous reviewers for their very helpful and constructive comments on an earlier version of this paper.

${ }^{2}$ More junior jobs involve being a mystery shopper in the linguistic landscape to check correct signage or checking possible brand names for their appropriateness in a different language.

${ }^{3}$ It is worth pointing out that this quote is from the same interviewee who stated that language workers rely mostly on intuition.

${ }^{4}$ A colleague has irreverently referred to this formula as 'you whinged - we cringed'

(Greg Myers, personal communication, 1 November 2016).

\section{References}

Bhatia, V. K. (2016). Critical Genre Analysis: investigating interdiscursive performance in professional practice. Abingdon: Routledge.

Cameron, D. (2000). Styling the worker: gender and the commodification of language in the globalized service economy. Journal of Sociolinguistics, 4(3), 323-347.

Carter, R. (2003). Language awareness. ELT Journal, 57(1), 64-65.

Catenaccio, P., Cotter, C., De Smedt, M., Garzone, G., Jacobs, G., Macgilchrist, F., Lams, L., Perrin, D., Richardson, J. E., Van Hout, T., \& Van Praet, E. (2011). Towards a linguistics of news production. Journal of Pragmatics, 43(7), 1843-1852.

Chan, C. S. C. (2017). Investigating a research-informed teaching idea: the use of transcripts of authentic workplace talk in the teaching of spoken business English. English for Specific Purposes, 46, 72-89.

Clifton, J. (2012). Conversation analysis in dialogue with stocks of interactional knowledge: facework and appraisal interviews. Journal of Business Communication, 49(4), 283-311.

Codó, E. (2017). Language awareness in multilingual and multicultural organisations. In P. Garrett, P., \& J. M. Cots (Eds.), The Routledge Handbook of Language Awareness. Abingdon: Routledge.

Cornelissen, J. (2017). Corporate Communication: a guide to theory and practice. $5^{\text {th }}$ ed. London: Sage.

Chesebro, J. L. (2014). Professional Communication at Work: interpersonal strategies for career success. New York: Routledge. 
Creelman, V. (2017). Speaking like a human being: beyond social media top 10 lists to practical application. Paper presented at Discourse, Communication and Enterprise 9, 22-24 June, Birmingham/UK.

Darics, E., \& Koller, V. (2018). Language in Business, Language at Work. London: Palgrave Higher Education.

Delin, J. (2005). Brand tone of voice. Journal of Applied Linguistics, 2, 1-44.

Delin, J. (2017). Corporate language and design. In G. Mautner, \& F. Rainer (Eds.), Handbook of Business Communication: linguistic approaches (pp. 657-676). Berlin: de Gruyter.

Development Economics. (2015). The value of soft skills to the UK economy. Retrieved from http://backingsoftskills.co.uk/The $\% 20$ Value $\% 20$ of $\% 20$ Soft $\% 20$ Skills $\% 20$ to $\% 20$ the $\%$ 20UK\%20Economy.pdf.

Ereaut, G., \& Segnit, N. (2006). Warm words: how are we telling the climate story and can we tell it better? Institute for Public Policy Research. Retrieved from http://www.ippr.org/files/images/media/files/publication/2011/05/warm_words_1529. pdf?noredirect $=1$

Fairclough, N. (1992). Introduction. In N. Fairclough (ed.) Critical Language Awareness (pp. 1-29). Harlow: Longman.

Fairclough, N. (1999). Global capitalism and critical awareness of language. Language Awareness, 8(2), 71-83.

Friginal. E. (2009). The Language of Outsourced Call Centres: a corpus-based study of cross-cultural interaction. Amsterdam: Benjamins.

Garrett, P., \& J. Cots, J. M. (Eds.) (2017). The Routledge Handbook of Language Awareness. Abingdon: Routledge.

Griffith, B., \& Labercane, G. (1997). Language awareness and workplace literacy. Educational Practice \& Theory, 19(1), 69-73.

Heller, M. (2010). The commodification of language. The Annual Review of Anthropology, 39, 101-114.

Janks, H., \& R. Ivanič (1992). Critical language awareness and emancipatory discourse. In N. Fairclough (Ed.) Critical Language Awareness (pp. 305-331). Harlow: Longman. 
Kheovichai, B. (2014). Marketized university discourse: a synchronic and diachronic comparison of the discursive constructions of employer organizations in academic and business job advertisements. Discourse \& Communication, 8(4), 371-390.

Köster, A., \& M. Handford (2012). Business Advantage B1. Cambridge: Cambridge University Press.

Koomen, J. (2014). Language work at international criminal courts. International Feminist Journal of Politics, 16(4), 581-600.

MacLeod, N., \& Haworth, K. (2016). Developing a linguistically informed approach to police interviewing. In R. Lawson, \& D. Sayers (Eds.), Sociolinguistic Research: application and impact (pp. 151-170). Abingdon: Routledge.

Mautner, G. (2010). Language and the Market Society: critical reflections on discourse and dominance. New York: Routledge.

Mautner, G. (2014). Englische Grammatik für die Wirtschaftskommunikation. $3^{\text {rd }}$ ed. Vienna: Linde.

Ng, C. J. W. (2016). 'Hottest brand, coolest pedagogy': approaches to corporate branding in Singapore's higher education sector. Journal of Marketing for Higher Education, 26(1), 41-63.

Patrick, P. (2016). The impact of sociolinguistics on refugee status determination. In R. Lawson, \& D. Sayers (Eds.), Sociolinguistic Research: application and impact (pp. 235-256). Abingdon: Routledge.

Paveau, M.-A. (2011) Do non-linguists practice linguistics? An anti-eliminative approach to folk theories. AILA Review, 24, 40-54.

Project Management Institute (2013). The high cost of low performance: The essential role of communications. Newtown Square, PA: Project Management Institute, Inc.

Retrieved from http://www.pmi.org/Knowledge-Center/ /media/PDF/BusinessSolutions/The-High-Cost-Low-Performance-The-Essential-Role-ofCommunications.ashx.

Sammler, S., Müller, L., Otto, M., \& F. Macgilchrist (2016). Textbook Production in a Hybrid Age: Contemporary and Historical Perspectives on Producing Textbooks and Digital Educational Media. Retrieved from http://repository.gei.de/handle/11428/211

Santos, V. B. M. P. dos (1994). Language awareness of non-native speakers in the business field. Language Awareness, 3(3-4), 201-208. 
Sarangi, S. (2002). Discourse practitioners as a community of interprofessional practice: some insights from health communication research. In C. N. Candlin (Ed.), Research and Practice in Professional Discourse (pp. 95-136). Hong Kong: City University of Hong Kong Press.

Svalberg, A. M.-L. (2016). Language awareness research: where are we now? Language Awareness, 25(1-2), 4-16.

Thurlow, C. (2017). Critical discourse studies in/of applied contexts. In J. Flowerdew and J. Richardson (eds), The Routledge Handbook of Critical Discourse Analysis (pp. 323341). Abingdon: Routledge.

Urciuoli, B., \& LaDousa, C. (2013). Language management/labor. Annual Review of Anthropology, 42, 175-190.

Wallace, C. (1999). Critical language awareness: key principles for a course in critical reading. Language Awareness, 8(2), 98-110.

Weninger, C., \& Kan, and K. H.-Y. (2013). (Critical) language awareness in business communication. English for Specific Purposes, 32, 59-71.

Whitehouse, M. (2018). Financial analysts and their role in financial communication and investor relations. In A. V. Laskin (ed.), The Handbook of Financial Communication and Investor Relations (pp. 117-126). Malden. MA: John Wiley \& Sons.

Žagar, I. Ž. (2010). Topoi in critical discourse analysis. Lodz Papers in Pragmatics, 6(1), $3-27$. 


\begin{tabular}{|c|c|c|c|c|}
\hline Job title & Type of organisation & Gender & $\begin{array}{l}\text { Country or } \\
\text { region }\end{array}$ & $\begin{array}{l}\text { Short } \\
\text { reference }\end{array}$ \\
\hline \multicolumn{5}{|l|}{ Private sector } \\
\hline Chief operating officer & brand consulting company & male & UK & PRS1 \\
\hline Online marketing manager & retail company & male & UK & PRS2 \\
\hline PR assistant & TV channel & male & UK & PRS3 \\
\hline *Founder & forensic text analysis company & male & UK & PRS4 \\
\hline *Managing partner & language consulting company & male & UK & PRS5 \\
\hline *Founder & safety and communications consulting company & female & UK & PRS6 \\
\hline $\begin{array}{l}\text { *Senior analyst for leadership } \\
\text { development }\end{array}$ & investment bank & female & US & PRS7 \\
\hline *Senior analyst & healthcare communications consulting & female & US & PRS8 \\
\hline *Lead design researcher & design com & male & US & PRS9 \\
\hline \multicolumn{5}{|l|}{ Public sector } \\
\hline Communications advisor & central government & male & Eastern Europe & PBS10 \\
\hline Head of communications & TV company & male & UK & PBS11 \\
\hline
\end{tabular}




\begin{tabular}{lcccc}
\hline Third sector & & & & \\
\hline Digital project manager & think tank & female & UK & \\
Director of global campaigns & think tank & male & US & THS12 \\
\hline
\end{tabular}

Table 1: Interview partners (asterisks indicate published interviews) 


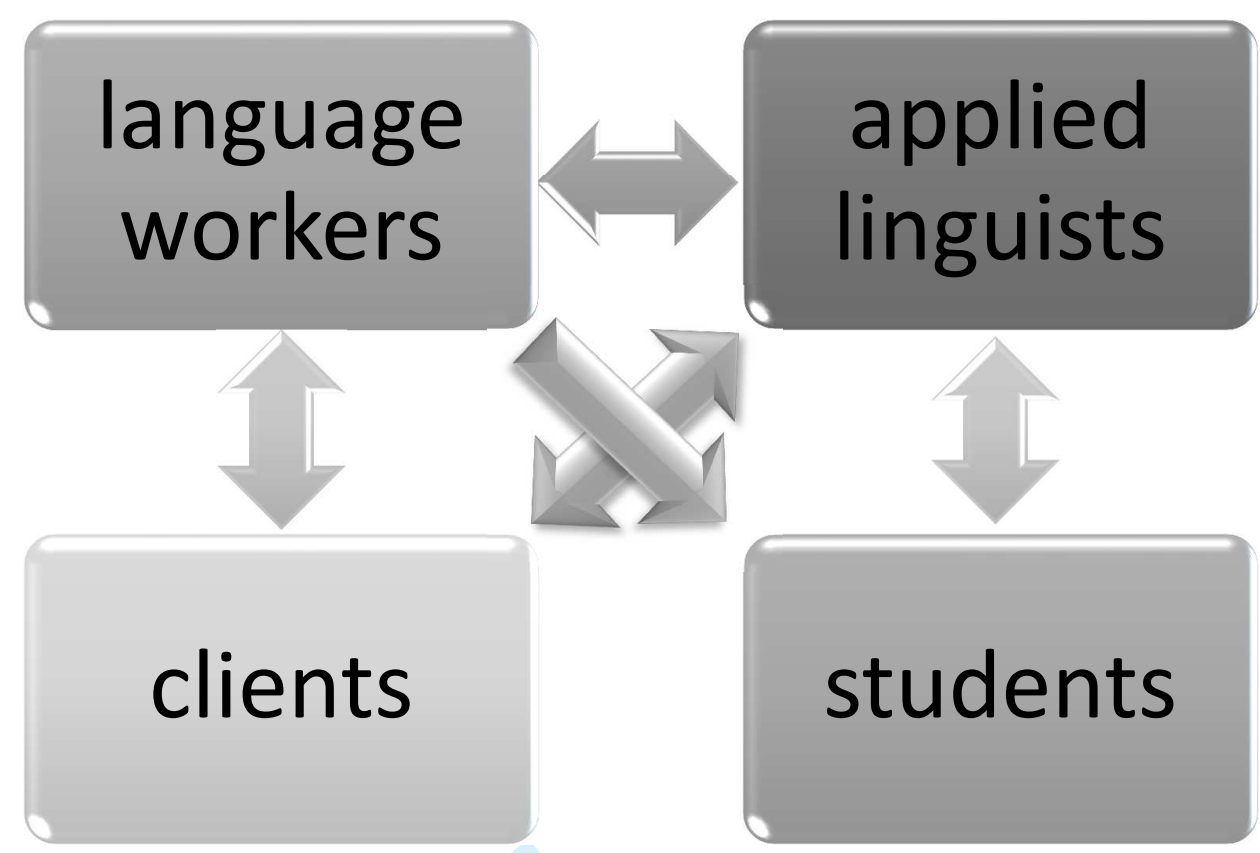

Figure 1: Learning and teaching relationships 